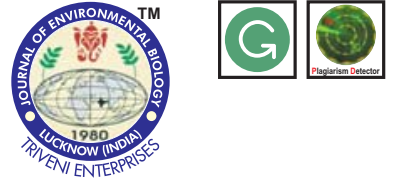

\title{
Comparative efficacy, non-target toxicity and economics of seven novel pre-mixed formulations against Maruca testulalis G. and Aphis craccivora K. infesting cowpea
}

Authors Info

D. Roy*, G. Chakraborty and P.K. Sarkar

Department of Agricultural Entomology, Bidhan Chandra Krishi Viswavidyalaya, Mohanpur, Nadia-741 252, India

${ }^{*}$ Corresponding Author Email : debashisroy915@gmail.com

Key words

Bean aphid Non-target toxicity,

Predators,

Ready-mix insecticides,

Spotted pod borer

Publication Info

Paper received : 21.03 .2016

Revised received: 17.06 .2016

Re-revised received : 07.09 .2016

Accepted:09.11.2016

\section{Abstract}

Aim: Cowpea is one of the most important legume vegetables commercially cultivated crop in India and is severely prone to attack by both chewing and sucking insect pests. As the most effective tool of IPM, proper selection of ready-mix insecticides is required for eco-friendly and simultaneous management of these insect pests to reduce the cost of protection. The main objective of the study was to evaluate the relative field-effectiveness vis.-a-vis. non-target toxicity and economics of seven new generation pre-mixed formulations against spotted pod borer (Maruca testulalis G.) and bean aphid (Aphis craccivora K.) infesting cowpea.

Methodology: Two rounds of insecticides spraying were done at $40-50 \%$ flowering stage, followed by next at 15 days interval. The number of target pests was counted $24 \mathrm{hrs}$ before first spray followed by $3,7,10$ and 14 days after first and second spray, respectively. Data of pod infestation was recorded 10 days after each spray and at harvest. Percent reduction or increase $(+)$ of Chrysoperla sp. and Micraspis discolor was also worked out at 15 days after each spray. Mean yield of green pods were recorded and converted into quintals perhectare.

Results: Chlorantraniliprole+thiamethoxam showed maximum impact (60.68\%) than emamectin benzoate + fipronil $(60.66 \%)$ and flubendiamide + thiacloprid $(60.35 \%)$ considering the mean percent reduction of pod damage caused by pod borer, while later proved most superior among all the test combinations in percent reduction of $M$. testulalis larval population with higher persistency. Highest aphid mortality was recorded in pyriproxyfen + fenpropathrin $(80.71 \%$ and $80.90 \%)$ and fipronil + imidacloprid $(79.24 \%$ and $79.54 \%$ ) treated plots after first and second spray, respectively, during both the years. Chlorantraniliprole + thiamethoxam and flubendiamide + thiacloprid proved least toxic to the prevailing predatory fauna Micraspis discolor (Fabricius) and Chrysoperla sp., with less than $10 \%$ mortality after 15 days of each insecticide imposition. Highest green pod and seed yield was also recorded from flubendiamide+thiacloprid (13.78 and $1.91 \mathrm{q} \mathrm{ha}^{-1}$ ) treated plots and highest cost: benefit ratio (1:6.8) was obtained from both the combinations of flubendiamide + thiacloprid and emamectin benzoate+fipronil.

Interpretation: The outcome of this study experiment will encourage the farming community in selecting new generation pre-mixed insecticides like flubendiamide $24 \%+$ thiacloprid $24 \%$ SC or chlorantraniliprole $10 \%$ +thiamethoxam $20 \%$ SC or emamectin benzoate $5 \%+$ fipronil $15 \%$ WDG, those might sustain toxicity against spotted pod borer and bean aphid for a longer period with least possibility of resistance development.

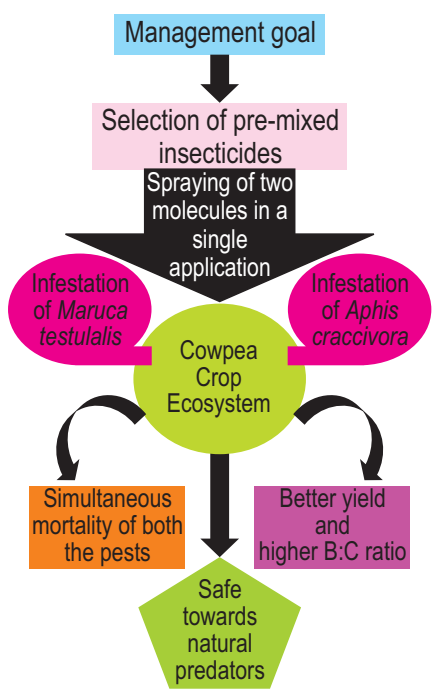




\section{Introduction}

Cowpea is a nutritionally important legume crop grown in semi arid and sub-humid tropics of Asia for both vegetables and pulses (Kumar and Kumar, 2015). High protein content of 23\%, carbohydrate $67 \%$, fat $1.3 \%$, fibre $1.8 \%$ and moister $8-9 \%$ are responsible to enrich the nutritional value of this crop (Jefferson, 2009). Majority of people in many developing countries are involved with cowpea cultivation and production (Singh and Singh, 2015), but the productivity is still low than its potential mainly due to the attack of different insects.

Spotted pod borer, Maruca testulalis is the most formidable and potential pest of cowpea, causing significant damage to the crops by infesting reproductive parts and tender pods (Kanhere et al., 2012). Scrapping followed by feeding on the seeds inside the pod by this pest, results in direct damage and a considerable yield loss up to $60 \%$ in cowpea (Pandey et al., 1991). Moreover, the typical cryptic feeding habit of $M$. testulalis larvae protects themselves from natural enemies and other environmental factors (Singh and Singh, 2015). On the other hand, bean aphid, Aphis craccivora (Koch) is one of the most important sap feeders which is solely responsible to cause 20$40 \%$ yield loss in cowpea (Reddy et al., 2014) and a major threat to cowpea growers throughout the country (Gauns et al., 2014). Entire seedling to pod bearing stage is most vulnerable to aphid attack when both nymphs and adults suck cell sap and cause stunting, crinkling and curling of leaves, delayed flowering, shriveling of pods and ultimately reduction in yield. Pesticide mixture may be in the form of tank-mix or pre-mix formulation that entails exposing individuals in a pest population to each of the active ingredient simultaneously (Hoy, 1998). The mixed pesticide formulations decrease labour cost by reducing the rounds of applications (Blackshaw et al., 1995), simultaneous by increase the mortality of different groups of arthropod pests having separate and distinct feeding habits (Warnock and Cloyd, 2005) and delaying resistance development against a particular pesticide by various pests (Bielza et al., 2009). Resistance problem in aphids and borers with higher mortality of natural enemies due to indiscriminate use of non-selective synthetic molecules, opened the new modern era of using mixtures of new molecules having novel mode of action for sustainable management of these pests. Hence, in order to manage these pests in cowpea, various control strategies like physical, biological, regulatory and chemical are followed and experimented by many researchers (Sharah and Ali, 2008); however, management practices for poor and marginal farming communities (Singh and Singh, 2015). Thus, the pre-mix insecticides having different mode of action may serve as a readyreckoner to the farmers, which can be applied on the hypotheses that they would complement the action of each other in simultaneous management of two target insect pests having different feeding habits. Keeping these views in backdrop, present study was undertaken to investigate the field bioeffectiveness vis.-a-vis. non-target toxicity and economics of some new generation pre-mixed formulations against spotted pod borer, M. testulalis and aphid, A. craccivora in cowpea.

\section{Materials and Methods}

Field bio-effectiveness was conducted on cowpea during June to September (kharif season) of 2014 and 2015 with a promising cultivar "Kashi Kanchan (VRCP-4)" at Horticulture Instructional Farm of Bidhan Chandra Krishi Viswavidyalaya, located at Mondouri, Nadia, West Bengal, India. The climate of the area is sub-humid tropical with average annual rainfall 1607.2 $\mathrm{mm}$. Sowing was done in the third week of June in $5 \times 4 \mathrm{~m}^{2}$ plot size and $40 \mathrm{~cm}$ (row to row) $\times 20 \mathrm{~cm}$ (plant to plant) spacing followed by recommended horticultural practices during both the years (Ahlawat and Shivakumar, 2012). A battery operated sprayer (V-Dyut Delux, Code: VBD09/TPHB4/SS/ WOB, ASPEE Sprayers and Farm Mechanised Equipment, Mumbai, 440064 , India) fitted with hollow cone nozzle of 16 I capacity was used for foliar spray of insecticides at the recommended level of @ 600 I spray volume with neutral $\mathrm{pH}$ per hectare.

Experiments were set in a completely randomized block design with eight treatments viz. flubendiamide $24 \%+$ thiacloprid 24\% SC @ $175 \mathrm{ml} \mathrm{ha}^{-1}$ (Tatagar et al., 2014), fipronil 40\% + imidacloprid 40\% WG@150 $\mathrm{g} \mathrm{ha}^{-1}$ (Patil et al., 2009), indoxacarb 14.5\% + acetamiprid 7.7\% SC @ $400 \mathrm{ml} \mathrm{ha}^{-1}$ (Kamble et al., 2014), cartap hydrochloride 50\% + buprofezin 10\% SC @ $600 \mathrm{ml}$ ha $^{-1}$ (Sarkar and Roy, 2015), pyriproxyfen 5\% + fenpropathrin 15\% EC @ $600 \mathrm{ml} \mathrm{ha}^{-1}$, chlorantraniliprole 10\% + thiamethoxam 20\% SC @ $180 \mathrm{ml} \mathrm{ha}^{-1}$, emamectin benzoate 5\% + fipronil 15\% WDG @ $750 \mathrm{~g} \mathrm{ha}^{-1}$ (Sarkar et al., 2015) and one untreated control and each treatment was replicated thrice (Selvaraj et al., 2015). Treatments were imposed coinciding ETL of the target pests, $M$. testulalis and A. craccivora (at $40-50 \%$ flowering stage of cowpea) followed by next at 15 days interval. The number of aphid nymphs and adults (counted visually with a 10x magnifying lens on a white paper sheet after removing from $15 \mathrm{~cm}$ shoot tip with the help of a camel hair brush) and pod borer larvae (counted visually from flowers, buds and pods separately and the average values were worked out) were recorded early in the morning (between 5.45 to $7.00 \mathrm{am}$ ) from ten randomly selected and tagged plants in each replication $24 \mathrm{hrs}$ before first spray, followed by $3,7,10$ and 14 days after first and second spray, respectively. The total number of pods and pods damaged by $M$. testulalis were recorded 10 days after each spray and at harvest. From these data, percent pod damage was calculated. Percent reduction or increase in each of the pest population was converted into per cent mortality by the formula of Henderson and Tilton (1955).

The percent reduction or increase $(+)$ of important predators Chrysoperla sp. and Micraspis discolor prevailing in the crop agro ecosystem was also worked out based on their number 
at $15 \mathrm{~cm}$ shoot tip on ten randomly selected and tagged plants (Kumar and Kumar, 2015) at 15 days after each insecticidal spray. Mean yield of green pods were recorded from each of the treated plots and converted into $q \mathrm{ha}^{-1}$. The cost benefit ratios were worked out according to Sarao and Kaur (2014) for evaluating the cost effectiveness of the treatments (Singh and Singh, 2015). Observed data on natural enemies' reduction were presented by bar graphs with standard errors using MS Excel sheet. Fieldefficacy data were subjected to statistical analysis with one way ANOVA using SPSS (version 18.0: Inc., Chicago, IL, USA) software. Mean values were separated by Duncan's Multiple Range Test (Gomez and Gomez, 1984) at $p<0.05$ for interpretation of the results.

\section{Results and Discussion}

Percent mortality of $M$. testulalis and $A$. craccivora against different treatment schedules during 2014 and 2015 is shown in Table 1, which revealed that all the pre-mixed formulations were significantly superior over untreated control in the reduction of larval population and nymphal and adult stages, respectively. After first round of spray application, emamectin benzoate + fipronil was found to be most effective combination $(74.13 \%)$, followed by chlorantraniliprole + thiamethoxam $(73.40 \%)$ and flubendiamide + thiacloprid $(72.02 \%)$ respectively, in overall mean percent reduction of $M$. testulalis larval population over untreated control $\left(F_{7,14}=10.25, P=0.0012\right)$. Kaushik et al. (2016) reported that two rounds of spray at $50 \%$ flowering stage, followed by 25 days after first spray can be recommended to the farmers to manage $M$. vitrata in cowpea. Similarly, it is also clear that during the first season, lowest percent pod damage by $M$. testulalis was recorded in case of emamectin benzoate + fipronil which was statistically at par with chlorantra-niliprole + thiamethoxam and pyriproxyfen + fenpropathrin 10 days after first spray $\left(F_{7,14}=14.34, P=0.001\right)$, whereas at $10^{\text {th }}$ day after second spray, percent pod damage varied between $9.59-12.18 \%$ in different treatments found statistically at par with each other (Table 2). Patel et al. (2012) acknowledged that emamectin benzoate was highly effective over indoxacarb and spinosad in managing $M$. testulalis in cowpea. Effectiveness of emamectin benzoate against lepidopteran borer in vegetables has also been confirmed by Anil and Sharma (2010). At the same time, highest mean percent reduction of all the stages of aphid population was registered by pyriproxyfen + fenpropathrin $(80.71 \%)$, followed by fipronil + imidacloprid (79.24\%); whereas cartap hydrochloride + buprofezin, flubendiamide + thiacloprid and chlorantraniliprole + thiamethoxam was statistically at par in the mitigation of aphid after first spray $\left(F_{714}=9.68, P=0.001\right)$. Neonicotinoid insecticides proved much promising against cowpea aphid under field, as well as laboratory condition (Abd-Ella, 2014) which corroborates the

Table 1 : Relative efficacy of different pre-mix formulations against spotted pod borer Maruca testulalis and bean aphid Aphis craccivora infesting cowpea during kharif season of 2014 and 2015

\begin{tabular}{|c|c|c|c|c|c|c|}
\hline Treatments & $\begin{array}{l}\text { Dose } \\
\text { (g or ml } \\
\text { ha }^{-1} \text { ) }\end{array}$ & $\begin{array}{l}\text { PTC (per } \\
10 \text { plants) }\end{array}$ & $\begin{array}{l}\text { Mean } \% \\
\text { reduction/increase } \\
(+) \text { of larval } \\
\text { population of } M \text {. } \\
\text { testulalis after } 1^{\text {st }} \\
\text { spray (pooled data } \\
\text { of } 2014 \text { and } 2015 \text { ) }\end{array}$ & $\begin{array}{l}\text { Mean } \% \\
\text { reduction/increase } \\
(+) \text { of larval } \\
\text { population of } M . \\
\text { testulalis after } 2^{\text {nd }} \\
\text { spray(pooled data } \\
\text { of } 2014 \text { and } 2015 \text { ) }\end{array}$ & $\begin{array}{l}\text { Mean } \% \\
\text { reduction/increase } \\
(+) \text { of nymphs and } \\
\text { adults of } A \text {. } \\
\text { craccivora after } 1^{\text {st }} \\
\text { spray(pooled data } \\
\text { of } 2014 \text { and } 2015 \text { ) }\end{array}$ & $\begin{array}{l}\text { Mean } \% \\
\text { reduction/increase } \\
(+) \text { of nymphs and } \\
\text { adults of } A \text {. } \\
\text { craccivora after } 2^{\text {nd }} \\
\text { spray(pooled data } \\
\text { of } 2014 \text { and 2015) }\end{array}$ \\
\hline $\begin{array}{l}\text { Flubendiamide } 24 \%+ \\
\text { Thiacloprid } 24 \% \text { SC }\end{array}$ & 175 & 11.50 & $72.02 a b c$ & $79.99 a$ & $73.55 c$ & $77.30 \mathrm{bc}$ \\
\hline $\begin{array}{l}\text { Fipronil } 40 \%+\text { Imidacloprid } \\
40 \% \text { WG }\end{array}$ & 150 & 11.75 & $64.24 \mathrm{e}$ & $66.78 \mathrm{~cd}$ & 79.24ab & 79.54ab \\
\hline $\begin{array}{l}\text { Indoxacarb } 14.5 \%+ \\
\text { Acetamiprid } 7.7 \% \text { SC }\end{array}$ & 400 & 12.25 & $70.57 b c$ & $69.25 b$ & $71.81 d$ & $70.02 \mathrm{cde}$ \\
\hline $\begin{array}{l}\text { Cartap hydrochloride } 50 \%+ \\
\text { Buprofezin } 10 \% \text { SC }\end{array}$ & 600 & 13.00 & $68.38 \mathrm{~cd}$ & $68.67 \mathrm{bc}$ & $74.66 \mathrm{c}$ & $74.37 \mathrm{c}$ \\
\hline $\begin{array}{l}\text { Pyriproxyfen } 5 \%+ \\
\text { Fenpropathrin } 15 \% \text { EC }\end{array}$ & 600 & 11.25 & $68.34 d$ & $68.76 \mathrm{bc}$ & $80.71 a$ & $80.90 \mathrm{ab}$ \\
\hline $\begin{array}{l}\text { Chlorantraniliprole } 10 \%+ \\
\text { Thiamethoxam } 20 \% \text { SC }\end{array}$ & 180 & 12.75 & $73.40 \mathrm{ab}$ & $77.91 \mathrm{ab}$ & $72.74 \mathrm{~cd}$ & $72.43 \mathrm{~cd}$ \\
\hline $\begin{array}{l}\text { Emamectin benzoate } 5 \%+ \\
\text { Fipronil } 15 \% \text { WDG }\end{array}$ & 750 & 12.00 & $74.13 a$ & $75.65 a b$ & $70.29 d$ & $71.96 \mathrm{~cd}$ \\
\hline Untreated control & - & 12.50 & +39.17 & +44.21 & +21.83 & +29.19 \\
\hline $\operatorname{LSD}(0.05)$ & NS & 3.17 & 2.96 & 2.61 & 2.27 & \\
\hline SEM \pm & NS & 1.34 & 1.40 & 1.03 & 0.89 & \\
\hline
\end{tabular}

PTC = Pre Treatment Count; Mean values followed by different letters are significantly different (otherwise statistically at par) at $p<0.05$ by Duncan's Multiple Range Test 
Table 2 : Relative effectiveness of different pre-mix formulations against percent pod damage of cowpea by spotted pod borer Maruca testulalis during kharif season of 2014 and 2015

\begin{tabular}{|c|c|c|c|c|c|c|c|c|c|c|c|}
\hline \multirow[t]{2}{*}{ Treatments } & \multirow[t]{2}{*}{$\begin{array}{l}\text { Dose (gor } \\
\left.\mathrm{mlha}^{-1}\right)\end{array}$} & \multicolumn{3}{|c|}{$\begin{array}{l}\text { Percent pod damage by } \\
\text { M. testulalis during } 2014\end{array}$} & \multirow{2}{*}{$\begin{array}{l}\text { Mean \% } \\
\text { pod } \\
\text { damage } \\
\text { during } \\
\text { season I }\end{array}$} & \multicolumn{3}{|c|}{$\begin{array}{l}\text { Percent pod damage by } \\
\text { M. testulalis during } 2015\end{array}$} & \multirow{2}{*}{$\begin{array}{l}\text { Mean } \% \\
\text { pod } \\
\text { damage } \\
\text { during } \\
\text { season II }\end{array}$} & \multirow{2}{*}{$\begin{array}{l}\text { Overall } \\
\text { mean } \% \\
\text { pod } \\
\text { damage } \\
\text { (pooled) }\end{array}$} & \multirow{2}{*}{$\begin{array}{l}\text { Overall } \\
\text { mean } \% \\
\text { reduction } \\
\text { of pod } \\
\text { damage } \\
\text { over } \\
\text { control }\end{array}$} \\
\hline & & $\begin{array}{l}10 \text { days } \\
\text { after }^{\text {st }} \\
\text { spray }\end{array}$ & $\begin{array}{l}10 \text { days } \\
\text { after2 }^{\text {nd }} \\
\text { spray }\end{array}$ & $\begin{array}{l}\text { At } \\
\text { harvest }\end{array}$ & & $\begin{array}{l}10 \text { days } \\
\text { after }^{\text {st }} \\
\text { spray }\end{array}$ & $\begin{array}{l}10 \text { days } \\
{\text { after } 2^{\text {nd }}} \\
\text { spray }\end{array}$ & $\begin{array}{l}\text { At } \\
\text { harvest }\end{array}$ & & & \\
\hline $\begin{array}{l}\text { Flubendiamide } 24 \%+ \\
\text { Thiacloprid } 24 \% \text { SC }\end{array}$ & 175 & $13.79 \mathrm{bcde}$ & $10.83 b$ & $8.51 \mathrm{bc}$ & 11.04 & $12.24 \mathrm{de}$ & $8.71 b$ & $6.52 \mathrm{c}$ & 9.16 & 10.10 & 60.35 \\
\hline $\begin{array}{l}\text { Fipronil 40\%+ Imidacloprid } \\
40 \% \text { WG }\end{array}$ & 150 & $15.34 b$ & $12.18 b$ & $9.58 b$ & 12.37 & $14.38 \mathrm{bcd}$ & $11.91 b$ & $9.97 b$ & 12.09 & 12.23 & 51.98 \\
\hline $\begin{array}{l}\text { Indoxacarb } 14.5 \%+ \\
\text { Acetamiprid } 7.7 \% \text { SC }\end{array}$ & 400 & $14.29 \mathrm{bc}$ & $11.92 b$ & $9.59 b$ & 11.93 & $14.71 \mathrm{bc}$ & $11.88 b$ & $10.01 b$ & 12.20 & 12.07 & 52.61 \\
\hline $\begin{array}{l}\text { Cartap hydrochloride } \\
50 \%+\text { Buprofezin } 10 \% \text { SC }\end{array}$ & 600 & $13.99 \mathrm{bcd}$ & $11.49 b$ & $9.57 \mathrm{~b}$ & 11.68 & $15.23 b$ & $12.10 \mathrm{~b}$ & $9.95 b$ & 12.43 & 12.06 & 52.65 \\
\hline $\begin{array}{l}\text { Pyriproxyfen } 5 \%+ \\
\text { Fenpropathrin } 15 \% \text { EC }\end{array}$ & 600 & $12.46 \mathrm{cde}$ & $10.29 b$ & $9.22 \mathrm{bc}$ & 10.66 & $12.76 \mathrm{cde}$ & $10.31 \mathrm{~b}$ & $7.80 \mathrm{bc}$ & 10.29 & 10.48 & 58.85 \\
\hline $\begin{array}{l}\text { Chlorantraniliprole 10\%+ } \\
\text { Thiamethoxam } 20 \% \text { SC }\end{array}$ & 180 & 12.13de & $9.59 b$ & $8.12 b c$ & 9.95 & $11.85 \mathrm{e}$ & $10.26 b$ & $7.82 \mathrm{bc}$ & 9.98 & 9.97 & 60.68 \\
\hline $\begin{array}{l}\text { Emamectin benzoate } 5 \%+ \\
\text { Fipronil } 15 \% \text { WDG }\end{array}$ & 750 & $11.86 \mathrm{e}$ & $10.05 b$ & $7.74 \mathrm{c}$ & 9.88 & $12.99 \mathrm{bcde}$ & le $10.22 b$ & $7.23 \mathrm{c}$ & 10.15 & 10.02 & 60.66 \\
\hline Untreated control & - & $27.87 a$ & $27.13 a$ & $21.77 a$ & 25.59 & $29.03 a$ & $25.20 a$ & $21.83 a$ & 25.35 & 25.47 & - \\
\hline $\operatorname{LSD}(0.05)$ & 3.38 & 6.16 & 5.14 & 7.25 & 4.64 & 10.19 & 3.26 & 7.09 & NS & NS & \\
\hline SEM \pm & 0.90 & 1.45 & 1.48 & 2.19 & 1.48 & 2.57 & 0.87 & 2.50 & NS & NS & \\
\hline
\end{tabular}

Mean values followed by different letters are significantly different (otherwise statistically at par) at $p<0.05$ by Duncan's Multiple Range Test

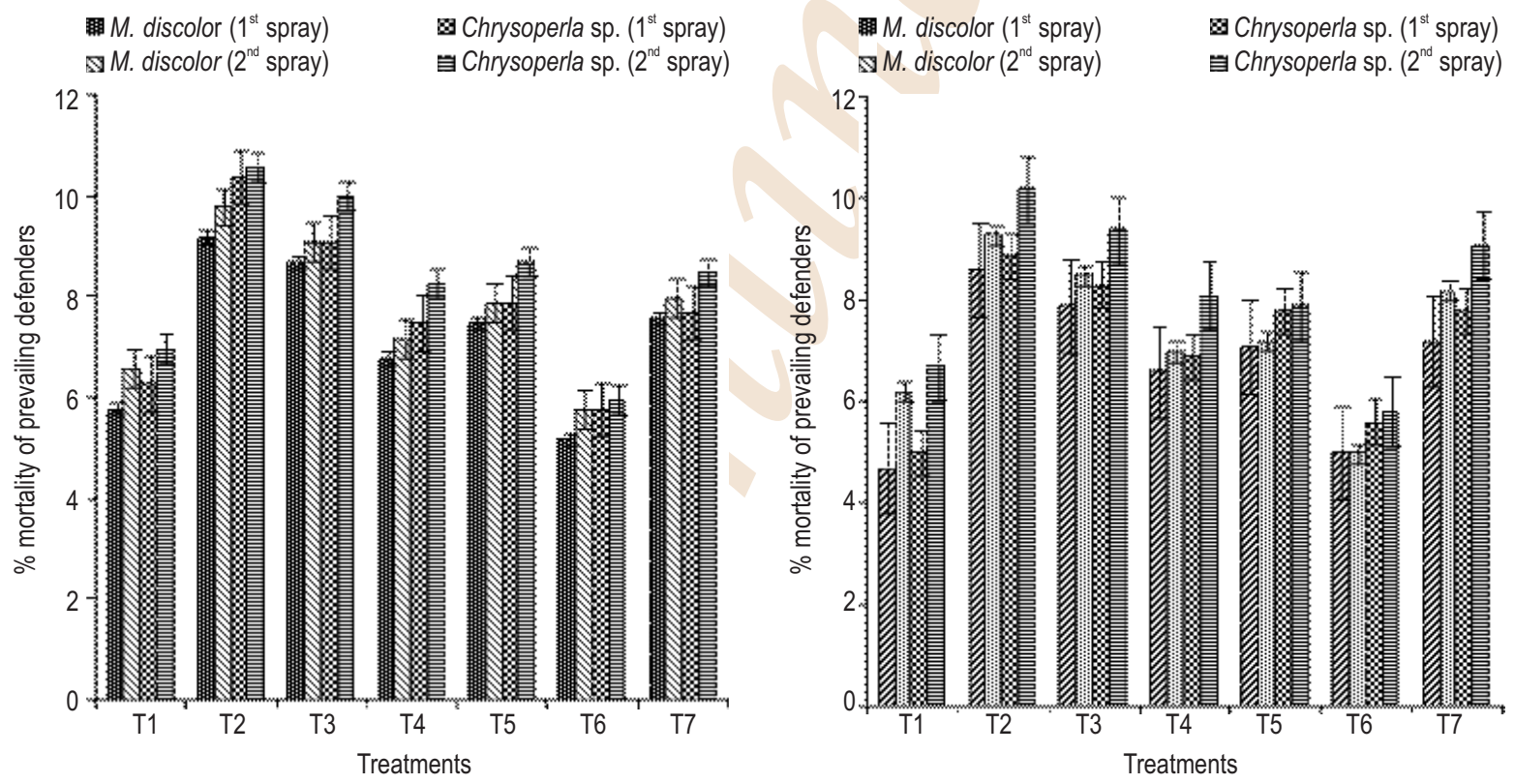

Fig. 1 : Percent mortality of prevailing natural enemies of cowpea crop-ecosystem after first and second spray of different pre-mix insecticides against spotted pod borer and aphid during kharif season of 2014 (A) and 2015 (B). (Vertical column followed by vertical bars are standard error of the mean) 
Table 3: Yield of cowpea and economics of different pre-mix insecticides against spotted pod borer Maruca testulalis (Geyer) and bean aphid Aphis craccivora (Koch) during kharif season of 2014 and 2015

\begin{tabular}{|c|c|c|c|c|c|c|c|c|c|c|}
\hline \multirow[t]{2}{*}{ Treatments } & \multirow[t]{2}{*}{$\begin{array}{l}\text { Dose(g } \\
\text { or ml } \\
\left.\text { ha }^{-1}\right)\end{array}$} & \multicolumn{2}{|c|}{$\begin{array}{l}\text { Mean yield of cowpea } \\
\text { during } 2014 \text { and } 2015 \\
\quad\left(q \text { ha }^{-1}\right)\end{array}$} & \multirow[t]{2}{*}{$\begin{array}{l}\text { Price of } \\
\text { chemicals } \\
\left(\text { Rs ha }^{-1}\right)\end{array}$} & \multirow[t]{2}{*}{$\begin{array}{l}\text { Labour } \\
\text { cost } \\
\left(\text { Rs ha }^{-1}\right)\end{array}$} & \multirow[t]{2}{*}{$\begin{array}{l}\text { Total cost of } \\
\text { treatment } \\
\left(\text { Rs ha }^{-1}\right)\end{array}$} & \multirow[t]{2}{*}{$\begin{array}{l}\text { Gross } \\
\text { return } \\
\text { (Rs ha') }\end{array}$} & \multirow[t]{2}{*}{$\begin{array}{l}\text { Net } \\
\text { return } \\
\left(\text { Rs ha }^{-1}\right)\end{array}$} & \multirow[t]{2}{*}{$\begin{array}{l}\text { Net profit } \\
\text { over control } \\
\left(\text { Rs ha }^{-1}\right)\end{array}$} & \multirow[t]{2}{*}{$\begin{array}{l}\mathrm{C}: \mathrm{B} \\
\text { ratio }\end{array}$} \\
\hline & & Green pod & Seed & & & & & & & \\
\hline $\begin{array}{l}\text { Flubendiamide } 24 \%+ \\
\text { Thiacloprid } 24 \% \text { SC }\end{array}$ & 175 & 13.78 & 1.91 & 2200.00 & 1176.00 & 3526.00 & 37463.4 & 33937.4 & 24059.8 & $1: 6.8$ \\
\hline $\begin{array}{l}\text { Fipronil } 40 \%+\text { +Imidacloprid } \\
40 \% \text { WG }\end{array}$ & 150 & 11.59 & 1.49 & 1760.00 & 1176.00 & 3086.00 & 30905.7 & 27819.7 & 17942.1 & $1: 5.8$ \\
\hline $\begin{array}{l}\text { Indoxacarb } 14.5 \%+ \\
\text { Acetamiprid } 7.7 \% \text { SC }\end{array}$ & 400 & 10.16 & 1.10 & 1825.00 & 1176.00 & 3151.00 & 26023.5 & 22872.5 & 12994.9 & 1:4.1 \\
\hline $\begin{array}{l}\text { Cartap hydrochloride } 50 \%+ \\
\text { Buprofezin } 10 \% \text { SC }\end{array}$ & 600 & 9.57 & 0.98 & 1650.00 & 1176.00 & 2976.00 & 24221.3 & 21245.3 & 11367.7 & $1: 3.8$ \\
\hline $\begin{array}{l}\text { Pyriproxyfen } 5 \%+ \\
\text { Fenpropathrin } 15 \% \text { EC }\end{array}$ & 600 & 10.32 & 1.18 & 1240.00 & 1176.00 & 2566.00 & 26758.3 & 24192.3 & 14314.7 & $1: 5.6$ \\
\hline $\begin{array}{l}\text { Chlorantraniliprole 10\%+ } \\
\text { Thiamethoxam } 20 \% \text { SC }\end{array}$ & 180 & 12.62 & 1.72 & 1980.00 & 1176.00 & 3306.00 & 34158.2 & 30852.2 & 20974.6 & $1: 6.3$ \\
\hline $\begin{array}{l}\text { Emamectin benzoate } 5 \%+ \\
\text { Fipronil } 15 \% \text { WDG }\end{array}$ & 750 & 13.25 & 1.84 & 2020.00 & 1176.00 & 3346.00 & 36040.4 & 32694.4 & 22816.8 & $1: 6.8$ \\
\hline Untreated control & - & 4.15 & 0.56 & 0.00 & 1176.00 & 1326.00 & 11203.6 & 9877.6 & - & - \\
\hline $\operatorname{LSD}(0.05)$ & 1.59 & 0.83 & - & - & - & - & - & - & - & \\
\hline SEM \pm & 0.32 & 0.20 & - & - & - & - & - & - & - & \\
\hline
\end{tabular}

Labour charges (skilled): Rs. 196.00 per day as per govt. of W.B. Labour Commission Circular, 2013; Sprayer charges Rs. 50.00 per day.

Price of cowpea pod Rs. 2000.00 per quintal and cowpea seed Rs. 5185.00 per quintal (http://agmarket.nic.in, All India level price range (Rs quintal ${ }^{-1}$ ) accessed on 11.02.2016)

findings of the present study. Swarnalata et al. (2015) proclaimed that imidacloprid $0.005 \%$ was significantly effective treatment over thiamethoxam, fipronil and cartap hydrochloride against cowpea aphid.

Almost similar trend of effectiveness of different premixed formulations against spotted pod borer larvae and bean aphid nymphs and adults was encountered after second round of spray (Table 1), where flubendiamide + thiacloprid (79.99\%) and pyriproxyfen + fenpropathrin $(80.90 \%)$ provided highest mean percent reduction of the target pests. Lowest mean percent pod damage was also recorded in flubendiamide + thiacloprid treated plots followed by chlorantraniliprole + thiamethoxam, emamectin benzoate + fipronil and pyriproxyfen + fenpropathrin $\left(F_{7,14}=20.27\right.$, $P=0.0001$ ) during 2015 (Table 2). These findings carborate the previous findings of Anusha et al. (2014) who reported that flubendiamide provided highest protection against pod borers of cowpea and was superior over emamectin benzoate and profenofos. Similarly, Dey et al. (2012) also conceded the efficacy of flubendiamide at 36 and $48 \mathrm{~g}$ a.i. ha ${ }^{-1}$ in enhancing yield against the attack of $M$. testulalis in pigeonpea. Moreover, chlorantraniliprole + thiamethoxam and emamectin benzoate + fipronil was statistically at par in the mean percent reduction of larval population of $M$. testulalis $\left(F_{7,14}=12.32, P=0.0001\right)$, whereas fipronil + imidacloprid followed by flubendiamide + thiacloprid also proved to be significantly more effective than other combinations in the mean percent reduction of all the stages of $A$. craccivora $\left(\mathrm{F}_{7,14}=17.48, \mathrm{P}=0.0002\right)$. Superiority of premixed formulation of flubendiamide + thiacloprid over emamectin benzoate and indoxacarb against $M$. testulalis has been reported by Shivaraju et al. (2011). Findings of the present study are in conformity with the findings of Swami et al. (2010) who substantiated that flubendiamide registered significantly less incidence of M. testulalis in black gram. Mahalakshmi et al. (2016) also reported that integration of bio-pesticides with chemical compounds is an effective tool in the management of spotted pod borer on pulse crops. Richardson and Kutz (2007) acknowledged that juvenile hormone analogue pyriproxyfen, was highly effective in managing soybean aphid. Reddy et al. (2014) also conceded the efficacy of different insecticides in controlling the incidence of cowpea aphid.

The non-target toxicity of different treatments were recorded on prevailing natural enemies in cowpea eco-system has been depicted on Fig. 1. During first season, fipronil + imidacloprid showed highest percent reduction of $M$. discolor after $15^{\text {th }}$ day of first $(S E m \pm 0.25)$ and second (SEm \pm 1.08 ) imposition. Chlorantraniliprole + thiamethoxam followed by flubendiamide + thiacloprid showed mild effect on all the test combinations in the reduction of $M$. discolor after first and second spray. All the test combinations exhibited less than $11 \%$ mortality of Chrysoperla sp. during 2014. Similar trends were also 
observed during the second study period 2015. Pyriproxyfen + fenpropathrin and emamectin benzoate + fipronil proved quite similar in the safety evaluation against both the predatory fauna and found statistically at par. But, fipronil + imidacloprid exhibited $8.6 \%$ and $8.9 \%$ reduction of $M$. discolor after 15 days of first (SEm \pm 1.82 ) and second (SEm \pm 0.90 ) spray, whereas $9.3 \%$ and $10.2 \%$ reduction of Chrysoperla sp. after 15 days of first (SEm \pm 0.39 ) and second (SEm \pm 1.35 ) spray respectively. Pre-evaluated results of higher toxicity of fipronil against Chrysoperla (Medina et al., 2004) and imidacloprid against aphid feeding coccinellid predators (Andreev and Atanasova, 2005) fully support the present findings. Moreover, eco-toxicological evaluation of clorantraniliprole against Chrysoperla (Hussain et al., 2012), thiamethoxam against coccinellid predators (Dhaka et al., 2009) and flubendiamide against Chrysoperla and Coccinellids (Dey et al., 2012) are in parity with the present findings, where all these chemicals had mild effect on these aphid feeding predatory fauna.

Mean green pod and seed yield of cowpea was higher in plots treated with different insecticidal combinations than untreated control (Table 3). The highest green pod $\left(F_{714}=17.72, P\right.$ $=0.0003)$, as well as seed yield $\left(F_{7,14}=13.91, P=0.0001\right)$ was obtained in the treatment of flubendiamide + thiacloprid followed by emamectin benzoate + fipronil and chlorantraniliprole + thiamethoxam with $13.78,1.91 ; 13.25,1.84$ and $12.62,1.72 \mathrm{q} \mathrm{ha}^{-1}$ respectively. Highest benefit: cost ratio was obtained from flubendiamide + thiacloprid and emamectin benzoate + fipronil, which was superior over chlorantraniliprole + thiamethoxam, fipronil + imidacloprid and pyriproxyfen + fenpropathrin. Cartap hydrochloride + buprofezin showed lowest economic yield with least benefit: cost ratio among all the pre-mixed formulations.

Based on the findings of present investigation, it can be concluded that new generation pre-mixed molecules like flubendiamide $24 \%$ + thiacloprid 24\% SC @ $175 \mathrm{ml} \mathrm{ha}^{-1}$ or chlorantraniliprole 10\% + thiamethoxam 20\% SC @ $180 \mathrm{ml} \mathrm{ha}^{-1}$ or emamectin benzoate 5\% + fipronil 15\% WDG @ $750 \mathrm{~g} \mathrm{ha}^{-1}$ can be an effective combination for sustainable management of spotted pod borer and bean aphid infesting cowpea from entomological, eco-toxicological and economic point of view, which will enhance the choice of farming community in selecting chemicals from different groups in near future.

\section{Acknowledgments}

Authors are thankful to the HOD, Agricultural Entomology and the Director of Farms, BCKV, Kalyani, West Bengal, India for providing infrastructural facilities to carry out the research work.

\section{References}

Abd-Ella, A.A.: Toxicity and persistence of selected neonicotinoid insecticides on cowpea aphid, Aphis craccivora Koch (Homoptera: Aphididae). Arch. Phytopathol. Plant Prot., 47, 366-376 (2014).

Ahlawat, I.P.S. and B.G. Shivakumar: Kharif Pulses (Pigeonpea,
Greengram, Blackgram, Cowpea). In: Textbook of Field Crops Production- Foodgrain Crops, (Ed.: R. Prasad). Directorate of Knowledge Management in Agriculture, Indian Council of Agricultural Research, Pusa, New Delhi. Vol. I, p. 248-319 (2012).

Andreev, R. and D. Atanasova: Toxicity of insecticides to predatory ladybirds (Coleoptera: Coccinellidae) under laboratory conditions. Acta Entomol. Bulg., 11, 7-15(2005).

Anil and P.C. Sharma: Bioefficacy of insecticides against Leucinodes orbonalis on brinjal. J. Environ. Biol., 31, 399-402 (2010).

Anusha, C., R.A. Balikai and R.H. Patil: Management of cowpea pests through newer and conventional insecticides. Int. J. Agril. Statol. Sci., 10, 157-160 (2014).

Bielza, P., E. Fernandez, C. Gravalos and J. Albellan: Carbamates synergize the toxicity of acrinathrin in resistant western flower thrips (Thysanoptera: Thripidae). J. Econ. Entomol., 102, 393-397 (2009).

Blackshaw, R.P., A.D. Baylis and P.F. Chapman: Effect of tank mixing on economic threshold for pest control. Asp. Appl. Biol., 41, 41-49 (1995).

Dey, P.K., G. Chakraborty and A.K. Somchoudhury: Evaluation of flubendiamide $480 \mathrm{SC}$ against lepidopteran pod borers of pigeonpea (Cajanus cajan (L) Millsp.). J. Interacademicia, 16, 857862 (2012).

Dhaka, S.S., G. Singh, Y.P.S. Malik and A. Kumar: Efficacy of new insecticides against mustard aphid, Lipaphis erysimi (Kalt.). J. Oilseed Res., 26, 172 (2009).

Gauns, K.H., A.B. Tambe, S.M. Gaikwad and R.S. Gade: Seasonal abundance of insect pests against forage cowpea. Trends Biosci., 7,1200-1204 (2014)

Gomez, K.K. and A.A. Gomez: Statistical procedures for Agricultural Research. John Wiley and Sons, New York, p. 67-81 (1984).

Henderson, C.F. and F.W. Tilton: Test with acaricides against the brown wheat mite. J. Econ. Entomol., 48, 157-161 (1955).

Hoy, M.A.: Myths, models and mitigation of resistance to pesticides. Phil. Trans. Royal Soc. London Biol. Sci., 353, 1787-1795 (1998).

Hussain, D., A. Ali, R. Tariq, M.M. Hassan and M. Saleem: Comperative toxicity of some new chemistry insecticides on Chrysoperla carnea (Stephens) under laboratory conditions. J. Agric. Res. Lahore, 50, 509-515 (2012).

Jefferson, T.: Cowpea: A versatile crop for hot and dry conditions. Thomas Jefferson Agricultural Institute, West Nifong Soulevard, Colombia (2009).

Kamble, P.P., S.R. Kulkarni and S.K. Patil: Efficacy of newer combination insecticides against shoot and fruit borer, Earias vitella (Fabricius) on okra. Pest Manag. Hortil. Ecosyst., 20, 242-244 (2014).

Kanhere, R.D., V.N. Patel, P.S. Umbarkar and A.M. Kakde: Bio-efficacy of different insecticides against spotted pod borer, Maruca testulalis (Geyer) infesting cowpea. Legume Res., 35, 44-46 (2012).

Kaushik, A.K., S.K. Yadav and P. Srivastava: Field efficacy of insecticides and mixture against spotted pod borer, Maruca vitrata Fabricius on Cowpea. Ann. PI. Prot. Sci., 24, 89-92 (2016).

Kumar, A. and A. Kumar: Effect of abiotic and biotic factors on incidence of pests and predator in cowpea [Vigna unguiculata (L.) Walp.]. Legume Res., 38, 121-125 (2015).

Mahalakshmi, M.S., M. Sreekanth, M. Adinarayana, Y.P. Reni, Y.K. Rao and $\mathrm{E}$. Narayana: Incidence, bionomics and management of spotted pod borer [Maruca vitrata (Geyer)] in major pulse crops in India-Areview. Agril. Rev., 37, 19-26 (2016).

Medina, P., F. Budia, P-del. Estal, A. Adan and E. Vinuela: Toxicity of 
fipronil to predatory lacewing Chrysoperla carnea (Neuroptera: Chrysopidae). Biocontrol Sci. Technol., 14, 261-268 (2004).

Pandey, S.N., R. Singh, V.K. Sharma and P.W. Kanwat: Losses due to insect pests in some Kharifpulses. Indian J. Entomol., 53, 629-631 (1991).

Patel, P.S., I.S. Patel, B. Panickar and Y. Ravindrababu: Management of spotted pod borer, Maruca vitrata in cowpea through newer insecticides. Trends Biosci., 5, 149-151 (2012).

Patil, S.B., S.S. Udikeri, P.V. Matti, G.S. Guruprasad, R.B. Hirekurubar, H.M. Shaila and N.B. Vandal: Bio-efficacy of new molecule fipronil $5 \%$ SC against sucking pest complex in Bt cotton. Karnat. J. Agril. Sci., 22, 1029-1031 (2009).

Reddy, D.S., M.P. Latha, L.R. Chowdary and L.R. Kumar: Efficacy of chemical and botanical against cowpea aphid [Aphis craccivora (Koch)]. Bioinfolet, 11, 853-854 (2014).

Richardson, M.L. and D.L. Kutz: Effects of a juvenile hormone analogue, pyriproxyfen, on the apterous form of soybean aphid (Aphis glycines). J. Appl. Entomol., 131, 297-302 (2007).

Sarao, P.S. and H. Kaur: Efficacy of Ferterra $0.4 \%$ GR (chlorantraniliprole) against stem borers and leaffolder insectpests of basmati rice. J. Environ. Biol., 35, 815-819 (2014).

Sarkar, P.K., S. Chakrabarti and P. Rai: Effectiveness of pre-mix formulation fipronil 15\% + emamectin benzoate 5\% WDG against thrips (Scirtothrips dorsalis Hood) and fruit borer Helicoverpa armigera (Hübn) of chilli. J. Entomol. Res., 39, 135-139 (2015).

Selvaraj, K., V.R. Babu, B.S. Gotyal and S. Satpathy: Toxicity and bioefficacy of individual and combination of diversified insecticides against jute hairy caterpillar, Spilarctia obliqua. J. Environ. Biol., 36, 1409-1414 (2015).

Sharah, H.A. and E.A. Ali: Impact of insecticide spray regimes on insect abundance in cowpea (Vigna unguiculata) in North Eastern Nigeria. Int. J. Agric. Biol., 10, 255-260 (2008).

Shivaraju, C., C.T.A. Kumar, S. Sudhirkumar and M. Thippaiah: Efficacy of indigenous materials and new insecticide molecules against Maruca testulalis (Hubner) on black gram. Int. J. Plant Prot., 4, 214-216 (2011).

Singh, C. and N.N. Singh: Bioefficacy and economics of different insecticides against legume pod borer (Maruca vitrata Fabricius) infesting cowpea (Vigna unguiculata Walpers). Indian J. Agric. Res., 49, 358-362 (2015).

Swami, S.V.S.G., M.V. Ramana and Y.R. Krishna: Efficacy of insecticides against the spotted pod borer Maruca vitrata (Geyer) in black gram (Vigna mungo (L) Hepper) grown in rice fallow. Pest Manag. Econ. Zool., 18, 157-164 (2010).

Swarnalata, B., S.M. Patel, H.V. Pandya and S.D. Patel: Bio-efficacy of insecticides against aphid (Aphis craccivora Koch) infecting cowpea [Vigna unguiculata (L.) Walp.]. Asian J. Biosci., 10, $83-88$ (2015).

Tatagar, M.H., H.D. Mohankumar, R.K. Mesta and M. Shivaprasad: Bioefficacy of new molecule, flubendiamide $24 \%$ + thiacloprid $24 \%$ $48 \%$ SC against chilli thrips, Scirtothrips dorsalis. Karnataka J. Agril. Sci., 27, 25-27 (2014).

Warnock, D.F. and R.A. Cloyd: Effect of pesticide mixtures in controlling western flower thrips (Thysanoptera: Thripidae). J. Entomol. Sci., $40,54-66(2005)$. 